\title{
Biofunctionalized pectin hydrogels as 3D cellular microenvironments
}

Citation for published version (APA):

Neves, S. C., Gomes, D. B., Sousa, A., Bidarra, S. J., Petrini, P., Moroni, L., Barrias, C. C., \& Granja, P. L. (2015). Biofunctionalized pectin hydrogels as 3D cellular microenvironments. Journal of Materials Chemistry. B, Materials for Biology and Medicine, 3(10), 2096-2108. https://doi.org/10.1039/c4tb00885e

Document status and date:

Published: 01/01/2015

DOI:

10.1039/c4tb00885e

Document Version:

Publisher's PDF, also known as Version of record

Document license:

Taverne

Please check the document version of this publication:

- A submitted manuscript is the version of the article upon submission and before peer-review. There can be important differences between the submitted version and the official published version of record.

People interested in the research are advised to contact the author for the final version of the publication, or visit the DOI to the publisher's website.

- The final author version and the galley proof are versions of the publication after peer review.

- The final published version features the final layout of the paper including the volume, issue and page numbers.

Link to publication

\footnotetext{
General rights rights.

- You may freely distribute the URL identifying the publication in the public portal. please follow below link for the End User Agreement:

www.umlib.nl/taverne-license

Take down policy

If you believe that this document breaches copyright please contact us at:

repository@maastrichtuniversity.nl

providing details and we will investigate your claim.
}

Copyright and moral rights for the publications made accessible in the public portal are retained by the authors and/or other copyright owners and it is a condition of accessing publications that users recognise and abide by the legal requirements associated with these

- Users may download and print one copy of any publication from the public portal for the purpose of private study or research.

- You may not further distribute the material or use it for any profit-making activity or commercial gain

If the publication is distributed under the terms of Article $25 \mathrm{fa}$ of the Dutch Copyright Act, indicated by the "Taverne" license above, 


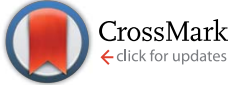

Cite this: J. Mater. Chem. B, 2015, 3 , 2096

\title{
Biofunctionalized pectin hydrogels as 3D cellular microenvironments $\uparrow$
}

\author{
Sara C. Neves, ${ }^{\text {abg }}$ David B. Gomes, ${ }^{\text {abg }}$ Aureliana Sousa, ag Silvia J. Bidarra, ${ }^{\text {ag }}$

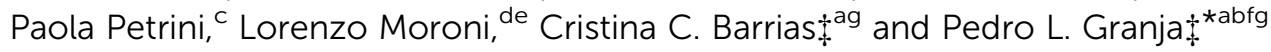

In situ-forming hydrogels of pectin, a polysaccharide present in the cell wall of higher plants, were prepared using an internal ionotropic gelation strategy based on calcium carbonate/D-glucono- $\delta$-lactone, and explored for the first time as cell delivery vehicles. Since no ultrapure pectins are commercially available yet, a simple and efficient purification method was established, effectively reducing the levels of proteins, polyphenols and endotoxins of the raw pectin. The purified pectin was then functionalized by carbodiimide chemistry with a cell-adhesive peptide (RGD). Its gelation was analyzed by rheometry and optimized. Human mesenchymal stem cells embedded within unmodified and RGD-pectin hydrogels of different viscoelasticities ( 1.5 and $2.5 \mathrm{wt} \%$ ) remained viable and metabolically active for up to 14 days. On unmodified pectin hydrogels, cells remained isolated and round-shaped. In contrast, within RGD-pectin hydrogels they elongated, spread, established cell-to-cell contacts, produced extracellular matrix, and migrated outwards the hydrogels. After 7 days of subcutaneous implantation in mice, acellular pectin hydrogels were considerably degraded, particularly the $1.5 \mathrm{wt} \%$ hydrogels. Altogether, these findings show the great potential of pectin-based hydrogels, which combine an interesting set of easily tunable properties, including the in vivo degradation profile, for tissue engineering and regenerative medicine.

Received 2nd June 2014

Accepted 26th January 2015

DOI: $10.1039 / c 4 t b 00885 e$

www.rsc.org/MaterialsB medicine strategies mainly due to their high water content and consequent viscoelastic and diffusive transport properties, which make them similar to the ECM of many tissues. ${ }^{1}$

A multitude of biomaterials have been explored to form hydrogels. The naturally derived ones either have structural characteristics similar to the native ECM or are components of it, like hyaluronic acid, which is found in all tissues of adult animals. ${ }^{1,2}$ Similarly, alginate and chitosan are hydrophilic, linear polysaccharides that can be extracted from abundant sources and have been widely investigated to obtain hydrogels for tissue engineering. ${ }^{3-5}$ Alginate hydrogels, for example, are biodegradable and can be processed under relatively mild conditions, which make them ideal candidates for cell entrapment and delivery. ${ }^{6,7}$

Among the naturally derived polymers, pectin, a complex structural polysaccharide present in the cell walls of higher plants, has been long used in the food industry as a gelling and thickening agent. It is mainly extracted from waste products of juice, apples and cider industries. ${ }^{8-10}$ Pectin extracts from cell walls are a family of polysaccharides with common features. The most familiar and predominant member is homogalacturonan (HG), mainly composed of a homopolymer of (1-4)-linked- $\alpha$-D-galacturonic acid (GalA) units. ${ }^{11}$ These can be partially esterified on the carboxyl group and by the acetyl group on the secondary hydroxyls. According to their degree of methylation (DM), pectins are divided into two categories: lowmethoxyl (LM) pectins (DM < 50\%) and high methoxyl (HM) 
pectins $(\mathrm{DM}>50 \%) .{ }^{12}$ Dissolved LM pectins can form gels in the presence of divalent metal ions, calcium being the most commonly used. For LM pectins, calcium-induced hydrogel formation is due to the chelation of calcium ions in regular arrays of electronegative cavities formed by GalA units. ${ }^{13}$ In LM pectin gels, the network is established via side-by-side association of the polysaccharide chains in solution. ${ }^{9}$

The interest in pectin has spread to the pharmaceutical and medical field as a natural prophylactic agent against toxic cations by chelation mechanisms, ${ }^{\mathbf{1 4}}$ in colon-specific drug delivery systems ${ }^{15}$ or, more recently, in the potential inhibitory role of pectin in cancer cell metastasis, invasion, and survival. ${ }^{\mathbf{8 , 1 6 , 1 7}}$ In tissue engineering and regenerative medicine applications there were just a few studies performed using pectin gels. ${ }^{18-22}$ Our group ${ }^{\mathbf{1 8 , 1 9}}$ has previously explored the external gelation of pectin with $\mathrm{CaCl}_{2}$ to obtain microspheres for the encapsulation of MC3T3 pre-osteoblast cells, which maintained a constant viability up to 29 days and were able to differentiate. Jahromi et al. ${ }^{22}$ embedded rat bone marrow stromal cells within citrus pectin hydrogels crosslinked by diffusion with $\mathrm{CaCl}_{2}$, within which cells were able to differentiate under osteogenic conditions. Takei and co-workers ${ }^{20,21}$ obtained sugar beet pectin (SBP) hydrogels by enzymatic crosslinking and the L929 fibroblast cells encapsulated in the gels were scarcely damaged during the gelation process. However, the use of $\mathrm{CaCl}_{2}$ leads to an immediate start of the gelation process and heterogeneous gelation. This hampers the use of this gelation strategy for in situ gelling systems. On its turn, enzymatic crosslinking demands additional modifications to the pectin structure that ionic crosslinking does not require.

To our knowledge, none has explored the potential of the internal ionotropic gelation of pectin using the slow-gelling calcium carbonate/D-glucono- $\delta$-lactone $\left(\mathrm{CaCO}_{3} / \mathrm{GDL}\right)$ system as an in situ-forming cell-delivery system. It has been used to produce alginate hydrogels for this purpose, ${ }^{6,7,23,24}$ and was also reported to be suitable to produce pectin gels for the food industry. ${ }^{25-27}$ However, the potential of pectin hydrogels crosslinked using this system for cell-delivery applications has not yet been explored. The internal gelation of pectin using $\mathrm{CaCO}_{3}$ (without GDL) was previously explored, ${ }^{28}$ showing how the internal gelation allows fine-tuning of the properties of the gels by an accurate control over the $\mathrm{pH}$ and the amount of $\mathrm{CaCO}_{3}$. However, until now, no cell embedding studies have been described for these gels.

Our interest in exploring pectin-based systems relies on the structural resemblance between pectin and alginate, allowing pectin to present the same numerous benefits of alginate for cell delivery, ${ }^{3,29}$ with the additional advantage of its interesting degradation profile under simulated physiological conditions, ${ }^{19}$ which could be important for applications requiring a fast hydrogel degradation. Moreover, much still remains to be elucidated about this polymer as a biomaterial.

In the present work, and prior to any studies, pectin was purified since there are no medical grade or ultrapure pectins commercially available yet. The purified pectin was further modified with the arginine-glycine-aspartic acid (RGD) containing peptide to promote integrin mediated cell adhesion.
The gelation kinetics of the purified and RGD-functionalized pectin was evaluated by rheometry. It was optimized to match a gelation time-frame adequate for an in situ-forming cell delivery system, i.e., the time needed for the mixing of the gelling components with the cell suspension and the injection of the mixture. Human mesenchymal stem cells (hMSCs), which are currently one of the most promising cell types in the regenerative medicine field for their ability to differentiate in multiple lineages under specific culture conditions, ${ }^{30}$ were embedded within these pectin hydrogels, and different cell studies were performed. Finally, acellular pectin hydrogel discs were subcutaneously implanted in the dorsum of mice for a preliminary assessment of their in vivo degradation.

\section{Experimental section}

\section{Pectin purification}

LM citrus pectin (Classic CU701), with a GalA unit content of $86 \%$ and a DM of $37 \%$, was kindly provided by Herbstreith \& Fox (Neuenbürg, Germany), and is hereafter referred to as raw pectin (RAWpec). Before any modification, pectin was purified (from now on referred to as purified pectin, PURpec) using a protocol based on Bender et al. ${ }^{31}$ Briefly, a 1 wt $\%$ RAWpec solution was prepared in ultrapure water (18 M $\Omega$, Milli-Q UltraPure Water System, Millipore). After the complete dissolution of the polymer, the $\mathrm{pH}$ of the solution was adjusted to 6 , activated charcoal ( $2 \mathrm{wt} \%$, Norit SX Plus, Norit) was added, and the suspension was stirred for $1 \mathrm{~h}$ at room temperature (RT). Then, the suspension was centrifuged for $1 \mathrm{~h}$ at $27000 \times \mathrm{g}$, the supernatant was carefully decanted, and the suspension was stirred once again for $30 \mathrm{~min}$. Afterwards, a second centrifugation with the same parameters was performed. The supernatant was filtered using $0.80 \mu \mathrm{m}, 0.45 \mu \mathrm{m}$, and finally $0.22 \mu \mathrm{m}$ filter membranes (mixed cellulose esters, MCE, Millipore), lyophilized, and stored at $-20{ }^{\circ} \mathrm{C}$ until further use.

The amount of protein contaminants present in the pectins was assessed using the Micro BCA Protein Assay Reagent Kit (Pierce Biotechnology, Rockford, IL, USA). Pectin solutions $(0.5 \mathrm{wt} \%$ in ultrapure water) $(n=3)$ were analyzed following the manufacturer's instructions and the absorbance was read at 540 nm using a micro-plate reader (Synergy MX, BioTek). For polyphenol quantification, the fluorescence spectra of pectin solutions ( $1 \mathrm{wt} \%$ in ultrapure water) were obtained following the protocol described by Skjåk-Bræk et al. ${ }^{32}$ An excitation wavelength of $366 \mathrm{~nm}$ was used and the emission spectra were recorded between 400 and $500 \mathrm{~nm}(n=3)$ using the previous micro-plate reader. The endotoxin content was assessed using the Food and Drug Administration (FDA, USA) approved Endosafe $^{\text {TM}}$-PTS system (Charles River, USA). The analysis was performed and certified by an external entity (Analytical Services Unit, IBET/ITQB, Oeiras, Portugal).

\section{Biofunctionalization of pectin}

The covalent grafting of the oligopeptidic sequence (Glycine) $4^{-}$ Arginine-Glycine-Aspartic acid-Serine-Proline (abbreviated as $\mathrm{G}_{4}$ RGDSP, Genscript, Piscataway, NJ, USA) to PURpec was 
carried out by aqueous carbodiimide chemistry, adapting the method previously described for alginate ${ }^{33,34}$ and more recently for pectin. ${ }^{18,19} \mathrm{~A} 1 \mathrm{wt} \%$ solution of PURpec was prepared at $4{ }^{\circ} \mathrm{C}$ in freshly prepared $0.1 \mathrm{M} 2-(\mathrm{N}$-morpholino) ethanesulfonic acid (MES) buffer solution (0.1 M MES buffering salt, $0.3 \mathrm{M} \mathrm{NaCl}, \mathrm{pH}$ adjusted to 6 using $1 \mathrm{M} \mathrm{NaOH}$, Sigma) in ultrapure water. Afterwards, the solution was divided into two: the PURpec solution to be modified (RGDpec) and the control, i.e., nonfunctionalized pectin (BLKpec). $N$-Hydroxy-sulfosuccinimide (sulfo-NHS, Pierce Chemical) and 1-ethyl-(dimethylaminopropyl)-carbodiimide (EDC, Sigma, $27.40 \mathrm{mg}$ per $\mathrm{g}$ pectin), at a molar ratio of $1: 2$, were sequentially added to the solutions, followed by the addition of $65.9 \mu \mathrm{mol}$ of RGD per gram of PURpec (only to the RGDpec solution). The solutions were left stirring for $20 \mathrm{~h}$ at $4{ }^{\circ} \mathrm{C}$. The reaction was quenched with hydroxylamine hydrochloride (18 $\mathrm{mg}$ per $\mathrm{g}$ pectin, Sigma), and the polymer solution was dialyzed (MWCO 3500, Spectra/Por®, SpectrumLabs) against decreasing concentrations of ultrapure water with $\mathrm{NaCl}$ for three days at $4{ }^{\circ} \mathrm{C}$. The solution was then mixed with activated charcoal ( $2 \mathrm{wt} \%)$, stirred for $1 \mathrm{~h}$, and centrifuged for $1 \mathrm{~h}$ at $27000 \times g$. The supernatant was then collected, stirred for $30 \mathrm{~min}$, and centrifuged again under the same conditions. The RGDpec and BLKpec solutions were then sterile filtered through $0.22 \mu \mathrm{m}$ filter membranes (Steriflip ${ }^{\circledR}$ filter unit, Millipore), lyophilized, and stored at $-20{ }^{\circ} \mathrm{C}$ until further use.

The extent of effective RGD coupling to PURpec was estimated by a UV absorbance assay in the $200-260 \mathrm{~nm}$ region, against BLKpec (1 wt\% in ultrapure water), using a 384-well UV transparent microplate (Greiner) in a micro-plate reader (PowerWave XS, BioTek) $(n=3)$. Absorbance readings were converted into the concentration of RGD using a calibration curve prepared with serially diluted RGD solutions mixed with BLKpec ( $1 \mathrm{wt} \%$ in ultrapure water) solutions as standards. The spectra were normalized against the $1 \mathrm{wt} \%$ BLKpec solution.

\section{Physico-chemical characterization of pectins}

Pectins were characterized by size exclusion chromatography (SEC) and Fourier transform infra-red spectroscopy (FTIR). The SEC analysis was performed at room temperature using a modular system, composed of an automated solvent/sample delivery unit (GPCmax, Viscotek), a viscometer/right angle laser light-scattering (RALLS) dual detector (T60, Viscotek) and a refractive index detector (K-5002, Knaeur). Separations were performed in a set of 3 PL aquagel-OH MIXED $8 \mu \mathrm{m}$ columns (Polymer Laboratories) with a guard column, using as the mobile phase $0.1 \mathrm{M} \mathrm{NaNO}_{3}$ with $0.02 \mathrm{wt} \% \mathrm{NaN}_{3}$, at a flow-rate of $1.0 \mathrm{~mL} \mathrm{~min}^{-1}$. Samples were dissolved in the mobile phase at 5 $\mathrm{mg} \mathrm{mL} \mathrm{m}^{-1}$ and injected $(100 \mu \mathrm{L})(n=3)$. Data were analyzed with the OmniSEC software (version 4.6.2., Viscotek). A refractive index increment of $d_{\mathrm{n}} / d_{\mathrm{c}}=0.147 \mathrm{mg} \mathrm{mL} \mathrm{m}^{-1}$ was employed. RAWpec had to be pre-processed prior to the SEC measurements. A RAWpec solution was prepared in MiliQ water (1 wt\%), its $\mathrm{pH}$ adjusted to 6, filtered through filter membranes (Millipore) to a final filtration of $0.22 \mu \mathrm{m}$, lyophilized, and dissolved in the mobile phase as described for the other samples. For the
FTIR spectroscopic analysis (Perkin-Elmer 2000), samples were dried under vacuum for $24 \mathrm{~h}$ and then prepared as pellets with $\mathrm{KBr}$ prior to the analysis. Each sample was analyzed using a wavelength range of $4000-400 \mathrm{~cm}^{-1}$ with $4 \mathrm{~cm}^{-1}$ steps (100 scans).

\section{Preparation of pectin hydrogel matrices and rheological characterization}

The preparation of in situ crosslinking pectin hydrogel matrices was based on the internal gelation strategy previously described for pectin in the food industry. ${ }^{25-27}$ It relies on the $\mathrm{CaCO}_{3} / \mathrm{GDL}$ system, in which GDL hydrolyses with time, lowering the $\mathrm{pH}$ of the solution, and triggering the slow release of $\mathrm{Ca}^{2+}$ from $\mathrm{CaCO}_{3}$ molecules. For the preparation of hydrogels, the lyophilized pectin was dissolved in $0.9 \mathrm{wt} \% \mathrm{NaCl}$ (in ultrapure water). Then an aqueous suspension of $\mathrm{CaCO}_{3}$ (Fluka) was thoroughly dispersed into the biopolymer solution, and a fresh solution of GDL (Sigma) was added. The $\mathrm{CaCO}_{3}$ and GDL quantities were determined according to the previously reported ${ }^{25,26}$ stoichiometric ratios, i.e., $\mathrm{Ca}^{2+}$-to- $\mathrm{COO}^{-}$present (eqn (1)) and the GDL needed for the number of $\mathrm{Ca}^{2+}$ in order to have a minimal effect on the final $\mathrm{pH}$ of the sample (eqn (2)). ${ }^{26}$ For these calculations, the $\mathrm{COO}^{-}$groups present on pectin were estimated from its DM. These ratios were then optimized for cell immobilization studies under standard cell incubation conditions $\left(37^{\circ} \mathrm{C}, 5 \%\right.$ $\left.\mathrm{CO}_{2}\right)$.

$$
\begin{gathered}
R=2\left[\mathrm{Ca}^{2+}\right] /\left[\mathrm{COO}^{-}\right] \\
R_{\mathrm{Ca}-\mathrm{GDL}}=2\left[\mathrm{Ca}^{2+}\right] /[\mathrm{GDL}]
\end{gathered}
$$

For the preparation of hydrogel cylinders $(\varnothing=5.5 \mathrm{~mm}$; height $=1.5 \mathrm{~mm}$ ), the hydrogel precursor solutions were loaded in a QGel® 3D disc caster (Lausanne, Switzerland). All RGDpec hydrogels were prepared with a final RGD density of $200 \mu \mathrm{M}$, which is similar to previously reported values found in biological ECMs. ${ }^{35}$

The rheological properties of pectin gel-precursor solutions and hydrogels were determined using a Kinexus Pro rheometer (Malvern Instruments, Malvern, UK), at $37{ }^{\circ} \mathrm{C}$ in a water-vapor saturated environment ensured by the rheometer chamber. For the oscillatory measurements, parallel plate geometries were used. The linear viscoelastic region (LVR) of the pectin hydrogels was determined using $\varnothing 8 \mathrm{~mm}$ sandblasted parallel plate geometries, compressing the gels by $10 \%$ of their height (oscillatory measurement gap), and iteratively performing strain amplitude sweep and frequency sweep measurements. The evolution of the viscoelastic properties of the pectin gels overtime was assessed with $\varnothing 20 \mathrm{~mm}$ sandblasted parallel plate geometries, using the frequency and shear strain values within the LVR. For each assay, the time was adjusted in order to match the time at which the GDL was added to the pectin hydrogel precursor solution.

The initial mesh size $(\xi)$ of pectin hydrogels was calculated using the value of the molecular weight between crosslinks $\left(M_{\mathrm{c}}\right)$, estimated from the shear modulus of the swollen pectin hydrogels (detailed calculations are provided in the ESI $\dagger$ ). 


\section{In vitro studies}

hMSCs culture. hMSCs isolated from bone marrow (Lonza) were cultured, expanded, and maintained in MSCGM (MSC growth medium, Lonza), at $37^{\circ} \mathrm{C}$ in a humidified atmosphere of $5 \% \mathrm{CO}_{2}$. The culture medium was changed twice a week and cells were trypsinized (0.05 wt $\%$ trypsin/ethylenediamine tetraacetic acid (EDTA) solution, Sigma) when they reached 70$80 \%$ confluence. Cells from passages between 6 and 8 were used in this study.

hMSCs culture within RGDpec hydrogels. Cells were trypsinized before reaching confluence and centrifuged. After discarding the supernatant, hMSCs were carefully mixed at a final concentration of $8 \times 10^{6}$ cells per $\mathrm{mL}$ with pectin hydrogel precursor solutions and crosslinking agents (as described in the section "Preparation of pectin hydrogel matrices and rheological characterization"). The cell pellet was mixed with the precursor solutions of RGDpec hydrogels, at final concentrations of 1.5 $\mathrm{wt} \%$ and $2.5 \mathrm{wt} \%$, and these were directly dispensed in the culture plates by placing $20 \mu \mathrm{L}$ of the solution into each well of a 2-poly(hydroxyethyl methacrylate) (pHEMA)-treated ${ }^{36} 24$ well plate. For the completion of gelling, samples were placed in the incubator $\left(37^{\circ} \mathrm{C}, 5 \% \mathrm{CO}_{2}\right.$ humidified atmosphere) for $1 \mathrm{~h}$. After this, cell culture medium (Dulbecco's modified Eagle medium with low glucose, DMEM, Gibco) supplemented with 10\% inactivated fetal bovine serum (HyClone, Thermo Scientific), and $1 \%$ penicillin/streptomycin (Gibco) was added to each well and changed after $24 \mathrm{~h}$. The cell-loaded pectin hydrogels were cultured for up to two weeks and medium was changed twice a week. As a control, cells were entrapped within BLKpec hydrogels and kept under the same conditions. Hydrogel cylinders with embedded cells were prepared by the same methodology, but using the QGel ${ }^{\circ} 3 \mathrm{D}$ disc caster (as described in the section "Preparation of pectin hydrogel matrices and rheological characterization"). For rheological analysis of pectin hydrogels with embedded cells after 7 days of culture, and in order to ensure the dimensional homogeneity of the samples, discs were punched with $\varnothing 4 \mathrm{~mm}$ biopsy punch cylinders just before analysis. The punched discs were compressed by $10 \%$ of their height (oscillatory measurement gap) and analyzed using $\varnothing 4$ $\mathrm{mm}$ sandblasted parallel plate geometries. The shear moduli components and phase angle values were averaged from the frequency sweeps (within the LVR, between $0.05 \mathrm{~Hz}$ and $0.5 \mathrm{~Hz}$ ).

Cell metabolic activity and viability. Metabolic activity was estimated using the resazurin-based assay. At different timepoints (1, 7 and 14 days), the culture medium was removed from the wells and fresh basal medium with $20 \mathrm{v} \%$ resazurin (Sigma) was added. Cell-loaded hydrogels were incubated $\left(37{ }^{\circ} \mathrm{C}, 5 \mathrm{v} \%\right.$ $\mathrm{CO}_{2}$ ) for $2 \mathrm{~h}$, after which $200 \mu \mathrm{L}$ per well were transferred to a black 96 well plate and measured $\left(\lambda_{\mathrm{ex}} \approx 530 \mathrm{~nm}, \lambda_{\mathrm{em}} \approx 590 \mathrm{~nm}\right.$ ) using a micro-plate reader (Synergy MX, BioTek). For the quantification of the total double-stranded DNA (dsDNA) content, the 3D matrices were dissolved, washed with PBS, and the suspension was centrifuged (10 $000 \mathrm{rpm}, 5 \mathrm{~min}$ ) to allow recovery of hMSCs. Samples were then stored at $-20{ }^{\circ} \mathrm{C}$ until further analysis. The dsDNA quantification was performed using the Quant-iT PicoGreen dsDNA kit (Molecular Probes,
Invitrogen), according to the manufacturer's instructions. Briefly, the frozen samples were thawed and lysed in $1 \% \mathrm{v} / \mathrm{v}$ Triton X-100 (in PBS) for $1 \mathrm{~h}$ at $250 \mathrm{rpm}$ and $4{ }^{\circ} \mathrm{C}$. Then, they were transferred to a black 96-well plate with clear bottom (Greiner) and diluted in TE buffer (200 mM Tris-HCl, $20 \mathrm{mM}$ EDTA, pH 7.5). After adding the Quant-iT PicoGreen dsDNA reagent, samples were incubated for $5 \mathrm{~min}$ at RT in the dark, and fluorescence was measured using a microplate reader $\left(\lambda_{\mathrm{ex}} \approx 480, \lambda_{\mathrm{em}} \approx 520 \mathrm{~nm}\right)$. The cell viability was qualitatively assessed using a live/dead assay. Cell-loaded pectin hydrogels were washed with DMEM without phenol red (Gibco) and incubated for $45 \mathrm{~min}\left(37^{\circ} \mathrm{C}, 5 \% \mathrm{CO}_{2}\right)$ with $1 \mathrm{mM}$ calcein-AM solution ( $\lambda_{\mathrm{ex}} \approx 494 \mathrm{~nm}, \lambda_{\mathrm{em}} \approx 517 \mathrm{~nm}$, Molecular Probes) and $2.5 \mathrm{mM}$ ethidium homodimer-1 solution $\left(\lambda_{\mathrm{ex}} \approx 528 \mathrm{~nm}, \lambda_{\mathrm{em}} \approx\right.$ $617 \mathrm{~nm}$, Molecular Probes). Immediately after incubation, cellloaded pectin matrices were visualized with a confocal laser scanning microscope (CLSM, Leica SP2AOBS, Leica Microsystems) using LCS software (Leica Microsystems). The scanned $Z$-series were projected onto a single plane and pseudo-colored using ImageJ.

Cell morphology and fibronectin deposition. For the same time-points as for the cell metabolic activity and viability assays, cell-loaded hydrogels were stained for filamentous actin (F-actin), fibronectin (FN), and nuclei. Briefly, samples were washed with $7.5 \mathrm{mM} \mathrm{CaCl}$ in Tris-buffered saline (TBS), fixed for $20 \mathrm{~min}$ in $4 \mathrm{wt} \%$ paraformaldehyde (PFA, Sigma), and permeabilized with $0.1 \%$ Triton X-100 (Sigma) for $5 \mathrm{~min}$. Samples were then incubated for $30 \mathrm{~min}$ with $1 \mathrm{wt} \%$ bovine serum albumin (BSA, Merck) in $7.5 \mathrm{mM} \mathrm{CaCl}_{2}$. For FN staining, matrices were incubated overnight at $4{ }^{\circ} \mathrm{C}$ with rabbit anti-fibronectin (f3648, Sigma, $1: 400)$ and then with the goat anti-rabbit secondary antibody Alexa Fluor ${ }^{\circledR} 594 \mathrm{~F}\left(\mathrm{ab}^{\prime}\right)_{2}$ fragment (Molecular Probes-Invitrogen, $1: 1000,1 \mathrm{~h}$ at RT). After this, samples were incubated with the conjugated probe phalloidin/Alexa Fluor ${ }^{\circledR} 488$ (Molecular Probes-Invitrogen, $1: 40,1 \mathrm{~h}$ at RT) for F-actin staining. Samples were subsequently washed three times with the $\mathrm{TBS} / \mathrm{CaCl}_{2}$ solution and nuclei were counterstained with $4^{\prime}$,6-diamidino-2-phenylindole dihydrochloride (DAPI, Sigma, $0.1 \mu \mathrm{g} \mathrm{mL}^{-1}$ ) in vectashield (vector), just before confocal visualization (CLSM, Leica SP2AOBS, Leica Microsystems) using LCS software (Leica Microsystems). The scanned $Z$-series were projected onto a single plane and pseudo-colored using ImageJ.

\section{In vivo studies}

Subcutaneous implantation of pectin hydrogels in mice. Acellular RGDpec hydrogel discs of $1.5 \mathrm{wt} \%$ and $2.5 \mathrm{wt} \%$ were prepared as described in the section "Preparation of pectin hydrogel matrices and rheological characterization" and incubated in cell culture medium $\left(37{ }^{\circ} \mathrm{C}, 5 \% \mathrm{CO}_{2}\right.$ humidified atmosphere) $24 \mathrm{~h}$ prior to implantation. All animal experiments were conducted following protocols approved by the Ethics Committee of the Portuguese Official Authority on Animal Welfare and Experimentation (DGV). Mice were housed at $22{ }^{\circ} \mathrm{C}$ with a $12 \mathrm{~h}$ light/dark cycle, and had ad libitum access to water and food. Male mice (C57BL/6, 5 weeks old, 17-19 g, $n=4$ ) were 
used as recipients. The animals were anesthetized by isofluorane inhalation, and anesthesia was maintained over the course of surgery by continuous isofluorane delivery. The dorsal surgical sites were shaved and sterilized. Two subcutaneous pockets were created per mouse for the insertion of the hydrogel discs ( $80 \mu \mathrm{L}$ per hydrogel). Acellular RGDpec hydrogel discs of $1.5 \mathrm{wt} \%$ (left flank) and $2.5 \mathrm{wt} \%$ (right flank) were placed in each mouse. After implantation, incisions were closed with sutures and analgesics were administrated $(0.05 \mathrm{mg}$ of Buprenorphine $\mathrm{HCl}$ per $\mathrm{kg}$ ). The animals were routinely monitored for general appearance, activity, and healing of the implant sites, and were euthanized after one week for retrieval of implants. No mice were lost during the study.

Histological evaluation. The harvested samples, which included the entire hydrogel discs and some surrounding tissue, were fixed in $10 \%$ neutral-buffered formalin overnight and processed for paraffin embedding. Using standard incubation conditions, samples were sectioned onto slides $(3 \mu \mathrm{m})$ and stained with Safranin-O/Light-green (Sigma). Hematoxylin was used as the counterstain.

\section{Statistical analysis}

Statistical analyses were performed using GraphPad Prism 5.0 software (version 5.0a). Data displayed in Table 1 regarding the measurements by SEC were analyzed using the unpaired $t$-test with Welch's correction. For the metabolic activity measurements normalized for the DNA content, the non-parametric Mann-Whitney test was used. For the rheological analysis of the discs with embedded cells, the two-way ANOVA statistical test with a Bonferroni post-test was applied to perform multiple comparisons amongst experimental conditions. All tests were

Table 1 Characterization of raw (RAWpec) and purified pectin (PURpec) by size exclusion chromatography (SEC)

\begin{tabular}{llll}
\hline & $\begin{array}{l}\text { Weight average, } \\
\text { molecular weight, } \\
M_{\mathrm{w}}(\mathrm{kDa})\end{array}$ & $\begin{array}{l}\text { Polydispersity, } \\
M_{\mathrm{w}} / M_{\mathrm{n}}\end{array}$ & $\begin{array}{l}\text { Intrinsic viscosity } \\
\left(\mathrm{dL} \mathrm{g}^{-1}\right)\end{array}$ \\
\hline RAWpec & $239.5 \pm 10.5$ & $3.0 \pm 0.1$ & $4.4 \pm 0.0^{* * *}$ \\
PURpec & $261.6 \pm 22.4$ & $3.1 \pm 0.2$ & $4.2 \pm 0.0$
\end{tabular}

performed using a 95\% confidence interval and statistically significant differences are marked with $*(p<0.05), * *(p<0.01)$ or $* * *(p<0.001)$.

\section{Results}

\section{Pectin purification, modification and characterization}

The most common contaminants found in plant-extracted polysaccharides - proteins, polyphenols, and endotoxins - were assessed for RAWpec and PURpec (Fig. 1A). The purification method lowered the protein content by $c a$. $70 \%$, the polyphenols content by $52 \%$, and the endotoxin levels by $96 \%$, when compared to RAWpec (Fig. 1B). After purification, pectin was functionalized with an RGD containing peptide and the UV spectrum (ESI Fig. $1 \dagger$ ) of RGDpec (normalized against BLKpec) showed the presence of a characteristic peak around $230 \mathrm{~nm}$, indicating that the peptide was effectively grafted to the polymer. The quantity of RGD coupled to PURpec was $15 \mathrm{mg}$ RGD per $g$ PURpec (a coupling yield of 30\%). The pectins were further characterized by FTIR (Fig. 1C) and SEC (Table 1).

The FTIR spectra of the different pectins showed the two main characteristic bands for pectin: ${ }^{19}$ the stretching of the carbonyl $(\mathrm{C}=\mathrm{O})$ in the methyl esters and $\mathrm{COOH}$ at $1735 \mathrm{~cm}^{-1}$ and the antisymmetric $\mathrm{COO}^{-}$stretching at $1630 \mathrm{~cm}^{-1}$. Minor differences could be observed when comparing the PURpec, BLKpec, and RGDpec spectra with the RAWpec spectrum.

From the SEC analysis of RAWpec and PURpec, the $M_{\mathrm{w}}$ and the polydispersity index $\left(M_{\mathrm{n}} / M_{\mathrm{w}}\right)$ were found to be similar. Though small, differences in the intrinsic viscosity were statistically significant. This might eventually indicate the occurrence of slight alterations in the polymer molecular conformation, possibly at the level of the secondary chains. ${ }^{37}$

\section{Optimization of pectin hydrogels}

The profile of pectin gelation was optimized towards cell embedding, attaining stabilization of the viscoelastic properties of the hydrogels within $1 \mathrm{~h}$ at $37^{\circ} \mathrm{C}$ (presenting a more "solidlike behavior", i.e., a phase angle ( $\delta$ ) below $10^{\circ}$ in less than $1 \mathrm{~h}$ ). Up to $R=0.5$ (eqn (1)), all $\mathrm{Ca}^{2+}$ present are theoretically bound in "egg-boxes", as suggested by Fraeye et al., ${ }^{9}$ considering the two-fold symmetrical conformation of pectin in "egg-boxes". In

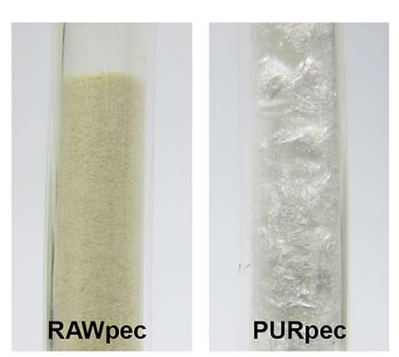

A

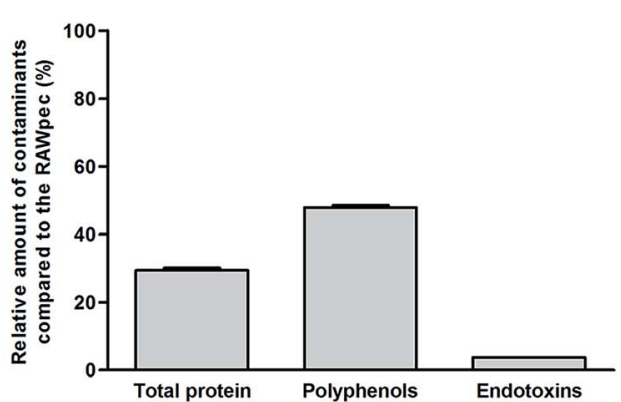

B

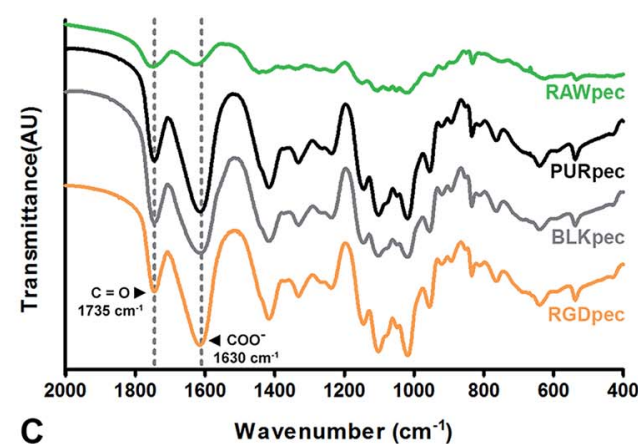

C

Wavenumber $\left(\mathrm{cm}^{-1}\right)$

Fig. 1 (a) Macroscopic appearance of RAWpec (powder) and PURpec (lyophilized foam). (b) Quantitative evaluation (as relative percentage) of the contaminants in PURpec compared to RAWpec. (c) Fourier transform infra-red (FTIR) spectra of the different pectins. 
$1.5 \mathrm{wt} \%$

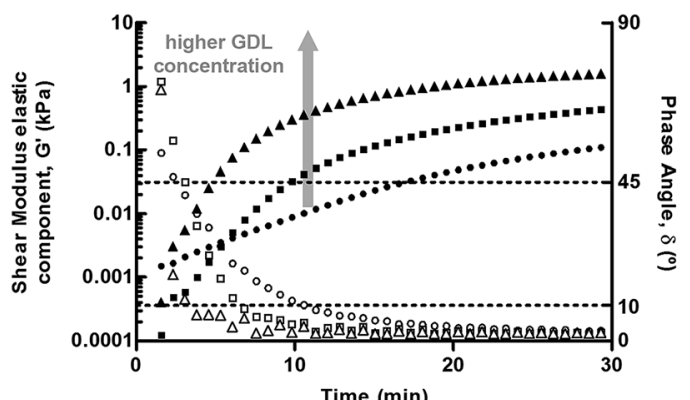

$2.5 \mathrm{wt} \%$

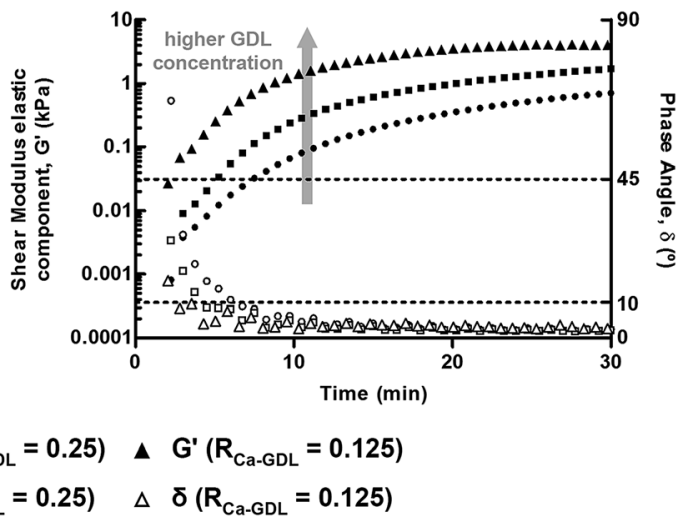

Fig. 2 Gelation kinetics of PURpec solutions using different ratios between the calcium ions and D-glucono- $\delta$-lactone (GDL) Content ( $R$ Ca-GDL values of $0.5,0.25$ and 0.125 , eqn (2)). The $R$-value was kept constant $(R=1$, eqn (1)).

this work, the $R$-value was kept at 1, representing an excess of $\mathrm{Ca}^{2+}$ for the formation of the "egg-boxes". This theoretical double amount of $\mathrm{Ca}^{2+}$ increases the probability that all possible "egg-box" zones are established. Regarding GDL concentration, three different $R_{\mathrm{Ca}-\mathrm{GDL}}$ values were tested -0.5 , 0.25 and 0.125 . The results for the $1.5 \mathrm{wt} \%$ and $2.5 \mathrm{wt} \%$ hydrogels (Fig. 2) show that all the three $R_{\mathrm{Ca}-\mathrm{GDL}}$ values lead to a $\delta$ lower than $10^{\circ}$ (a more "solid-like" behavior) for both formulations within $30 \mathrm{~min}$ (information regarding other pectin concentrations is presented in ESI Fig. $2 \dagger) . R_{\mathrm{Ca}-\mathrm{GDL}}=0.5$ was the one chosen for the following experiments as (i) it allows a slower transition from the "liquid-like" state to the more "solid-like" state (less accentuated $G^{\prime}, G^{\prime \prime}$ and $\delta$ slopes), which would be more adequate for cell embedding, and, as previously reported, (ii) it allows us to achieve a neutral $\mathrm{pH}$ post-crosslinking. ${ }^{23,38}$ From the LVR studies (ESI Fig. $3 \dagger$ ) of pectin hydrogels, the parameters selected for the gelation studies were $1 \%$ shear strain at a frequency of $0.1 \mathrm{~Hz}$. Both these studies variation of $R_{\text {Ca-GDL }}$ values and LVR determination - were performed with PURpec in order to use the same values of $R$, $R_{\text {Ca-GDL }}$, shear strain, and frequency for all further comparative gelation studies of the different pectins. To evaluate whether the purification procedure affects the gelling ability of pectin, the gelation kinetics of RAWpec and PURpec solutions was analyzed (ESI Fig. 4A $\dagger$ ). The purification led to a decrease in the gelation triggering time (i.e., the crossover time, $t_{\mathrm{gel}}-$ the time at which $\delta$ goes below $45^{\circ}$ and there is the crossover between the elastic $\left(G^{\prime}\right)$ and viscous $\left(G^{\prime \prime}\right)$ components of the shear modulus), for both hydrogel concentrations $\left(t_{\mathrm{gel}} 1.5 \% \mathrm{RAW} \approx 20 \mathrm{~min}\right.$,

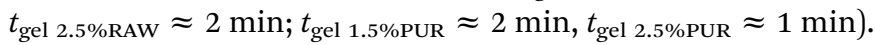
After $1 \mathrm{~h}$, both RAWpec and PURpec hydrogels presented a more "solid-like" behavior $\left(\delta<10^{\circ}\right)$; however, the PURpec gels presented higher shear moduli $\left(G_{1.5 \% \mathrm{PUR}}^{\prime} \approx 0.102 \mathrm{kPa}, G_{1.5 \% \mathrm{PUR}}^{\prime \prime} \approx\right.$ $0.009 \mathrm{kPa} ; G_{2.5 \% \mathrm{PUR}}^{\prime} \approx 0.972 \mathrm{kPa}, G_{2.5 \% \mathrm{PUR}}^{\prime \prime} \approx 0.031 \mathrm{kPa}$ ) when compared to the RAWpec gels $\left(G_{1.5 \% \mathrm{RAW}}^{\prime} \approx 0.047 \mathrm{kPa}, G_{1.5 \% \mathrm{RAW}}^{\prime \prime}\right.$ $\left.\approx 0.003 \mathrm{kPa} ; G_{2.5 \% \mathrm{RAW}}^{\prime} \approx 0.513 \mathrm{kPa}, G_{2.5 \% \mathrm{RAw}}^{\prime \prime} \approx 0.017 \mathrm{kPa}\right)$. The effect of the presence of RGD on pectin gelation was also assessed (ESI Fig. 4B †). The gelation triggering time was barely

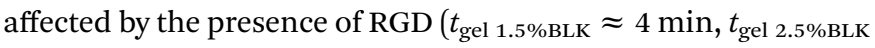

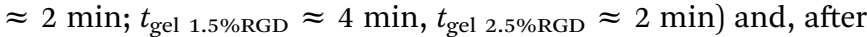
$1 \mathrm{~h}$, the BLKpec gels presented shear moduli values $\left(G_{1.5 \% \mathrm{BLK}}^{\prime} \approx\right.$ $0.589 \mathrm{kPa}, G_{1.5 \% \mathrm{BLK}}^{\prime \prime} \approx 0.016 \mathrm{kPa} ; G_{2.5 \% \text { BLK }}{ }^{\prime} \approx 1.390 \mathrm{kPa}$, $\left.G_{2.5 \% \mathrm{BLK}}^{\prime \prime} \approx 0.041 \mathrm{kPa}\right)$ similar to the RGDpec gels $\left(G_{1.5 \% \mathrm{RGD}}^{\prime} \approx\right.$ $0.349 \mathrm{kPa}, G_{1.5 \% \mathrm{RGD}}^{\prime \prime} \approx 0.010 \mathrm{kPa} ; G_{2.5 \% \mathrm{RGD}}^{\prime} \approx 1.698 \mathrm{kPa}$, $G_{2.5 \% \mathrm{RGD}}^{\prime \prime} \approx 0.053 \mathrm{kPa}$ ). Finally, the influence of the presence of cells on the gelation kinetics of BLKpec and RGDpec was also evaluated (ESI Fig. 4C $\dagger$ ). Cells slightly affected the process. The cross-over times were barely affected $\left(t_{\text {gel } 1.5 \% \text { BLKcells }} \approx 5 \mathrm{~min}\right.$, $t_{\text {gel } 2.5 \% \text { BLKcells }} \approx 3 \mathrm{~min} ; t_{\text {gel } 1.5 \% \text { RGDcells }} \approx 5 \mathrm{~min}, t_{\text {gel } 2.5 \% \text { RGDcells }} \approx$ $3 \mathrm{~min}$ ). After $1 \mathrm{~h}$, the viscoelastic properties of the gels were slightly different, with the shear moduli presenting higher values for the hydrogels without cells $\left(G_{1.5 \% \text { BLKcells }}^{\prime} \approx 0.197 \mathrm{kPa}\right.$, $G_{1.5 \% \text { BLKcells }}^{\prime \prime} \approx 0.009 \mathrm{kPa} ; G_{1.5 \% \text { RGDcells }}^{\prime} \approx 0.188 \mathrm{kPa}$, $G_{1.5 \% \text { RGDcells }}^{\prime \prime} \approx 0.008 \mathrm{kPa} ; G_{2.5 \% \text { BLKcells }}^{\prime} \approx 0.933 \mathrm{kPa}$, $G_{2.5 \% \text { BLKcells }}^{\prime \prime} \approx 0.033 \mathrm{kPa} ; G_{2.5 \% \text { RGDcells }}^{\prime} \approx 0.792 \mathrm{kPa}$, $\left.G_{2.5 \% \text { RGDcells }}^{\prime \prime} \approx 0.028 \mathrm{kPa}\right)$.

From the rheological analysis of swollen pectin hydrogels it was possible to calculate their initial mesh size (ESI $\dagger$ ), which was higher for the $1.5 \mathrm{wt} \%$ hydrogels $\left(\xi_{1.5 \mathrm{wt} \%} \approx 707 \mathrm{~nm}\right)$ when compared to the $2.5 \mathrm{wt} \%$ hydrogels $\left(\xi_{2.5} \mathrm{wt} \% \approx 380 \mathrm{~nm}\right)$.

\section{hMSCs embedded within the pectin matrices}

According to the qualitative assessment of the cell viability and the metabolic activity measurements (Fig. 3), hMSCs remained viable and metabolically active throughout the 14 days of culture in all formulations tested, and no significant differences could be observed between the different hydrogel formulations over time, despite their structural differences (mesh size and viscoelastic properties). The only significant differences were found between the $1.5 \mathrm{wt} \%$ RGDpec and $1.5 \mathrm{wt} \%$ BLKpec for days 1 and 14 of culture. However, hMSCs presented different morphologies depending on the matrix within which they were embedded (Fig. 4). They were able to spread and establish cell-to-cell contacts inside the RGDpec hydrogels, but they remained round on the BLKpec matrices throughout the 14 days experiment. Regarding the RGDpec hydrogels, hMSCs could establish a denser cell-to-cell network 
$1.5 \mathrm{wt} \%$
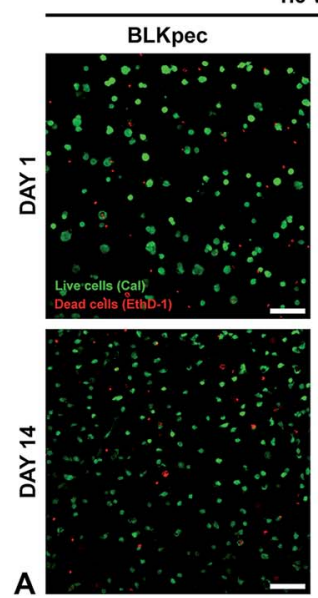
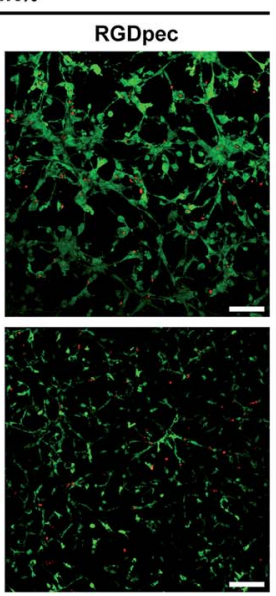

$2.5 \mathrm{wt} \%$

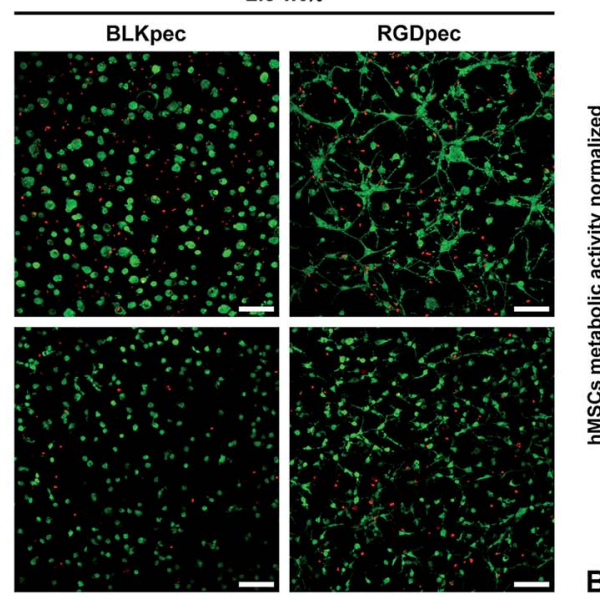

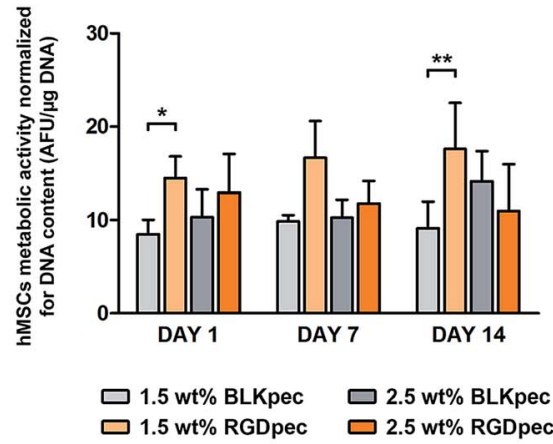

Fig. 3 (a) Viability of human mesenchymal stem cells (hMSCs) embedded within the pectin hydrogels after 1 and 14 days of culture. Live cells are stained by calcein AM (Cal, green) and dead cells by ethidium homodimer-1 (EthD-1, red). Scale bars: $100 \mu$ m. (b) Metabolic activity (normalized for the DNA content) of human mesenchymal stem cells (hMSCs) embedded within the pectin hydrogels after 1, 7 and 14 days of culture. Statistically significant differences are marked as $*(p<0.05)$ and $* *(p<0.01)$.

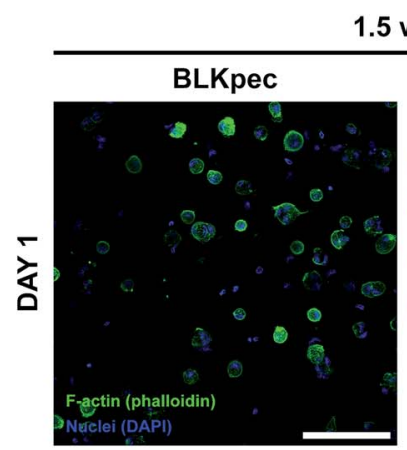

$1.5 \mathrm{wt} \%$
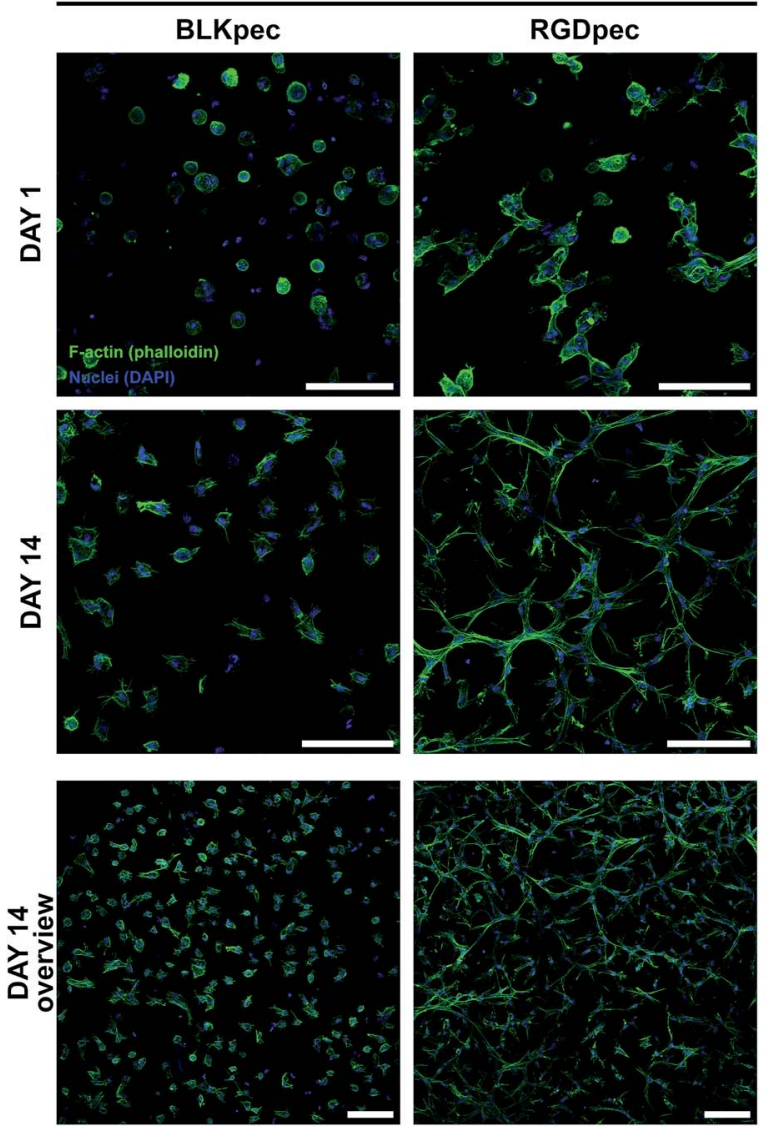
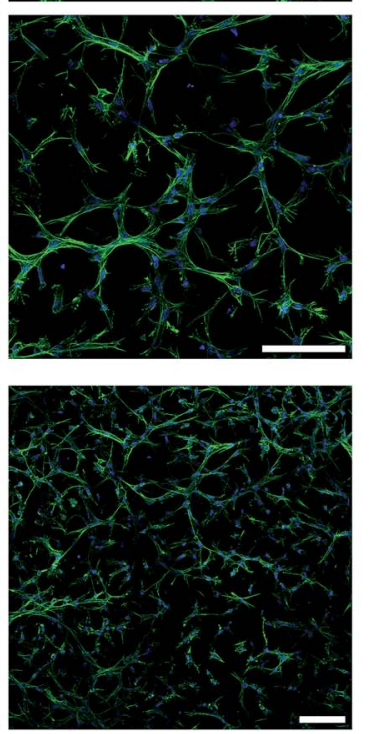

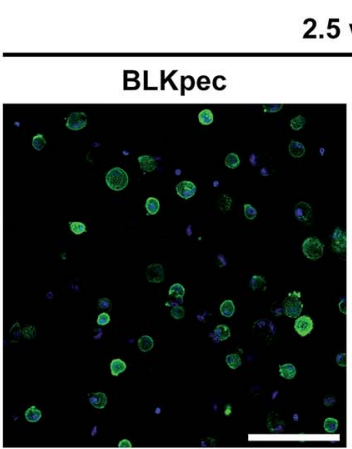

$2.5 \mathrm{wt} \%$
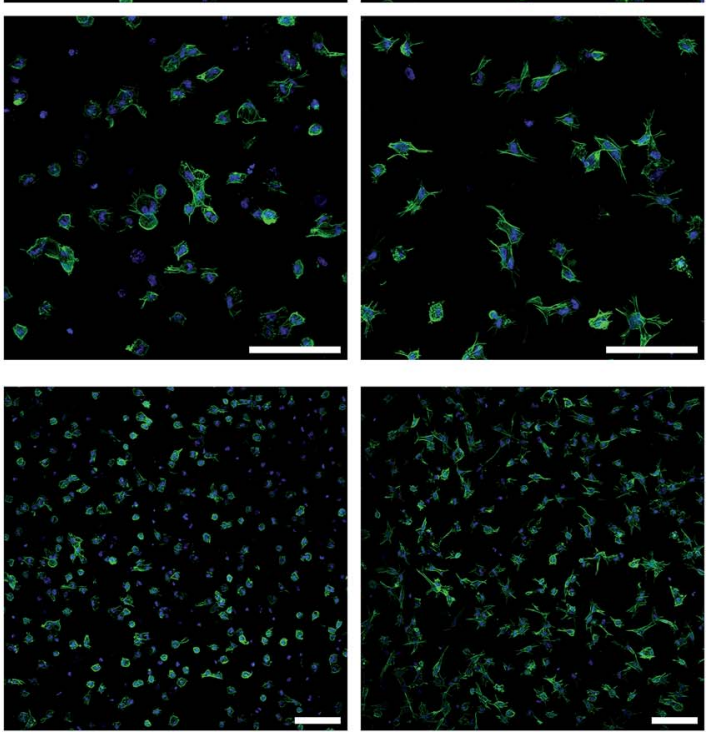

Fig. 4 Morphology and spatial arrangement of human mesenchymal stem cells (hMSCs) embedded within the different pectin hydrogels after 1 and 14 days of culture, stained for F-actin (green) and nuclei (blue) (scale bars: $100 \mu \mathrm{m}$ ).

within the $1.5 \mathrm{wt} \%$ concentration than on the $2.5 \mathrm{wt} \%$ hydrogels.

From the macroscopic evaluation of the pectin hydrogels after 7 days of culture (Fig. 5A), the size of the BLKpec hydrogels was similar to that of day 1 (data not shown), in contrast to the RGDpec hydrogels, whose size decreased from day 1 to day 7 . At day 7, it could be observed that the RGDpec hydrogels appeared to be smaller than the BLKpec 

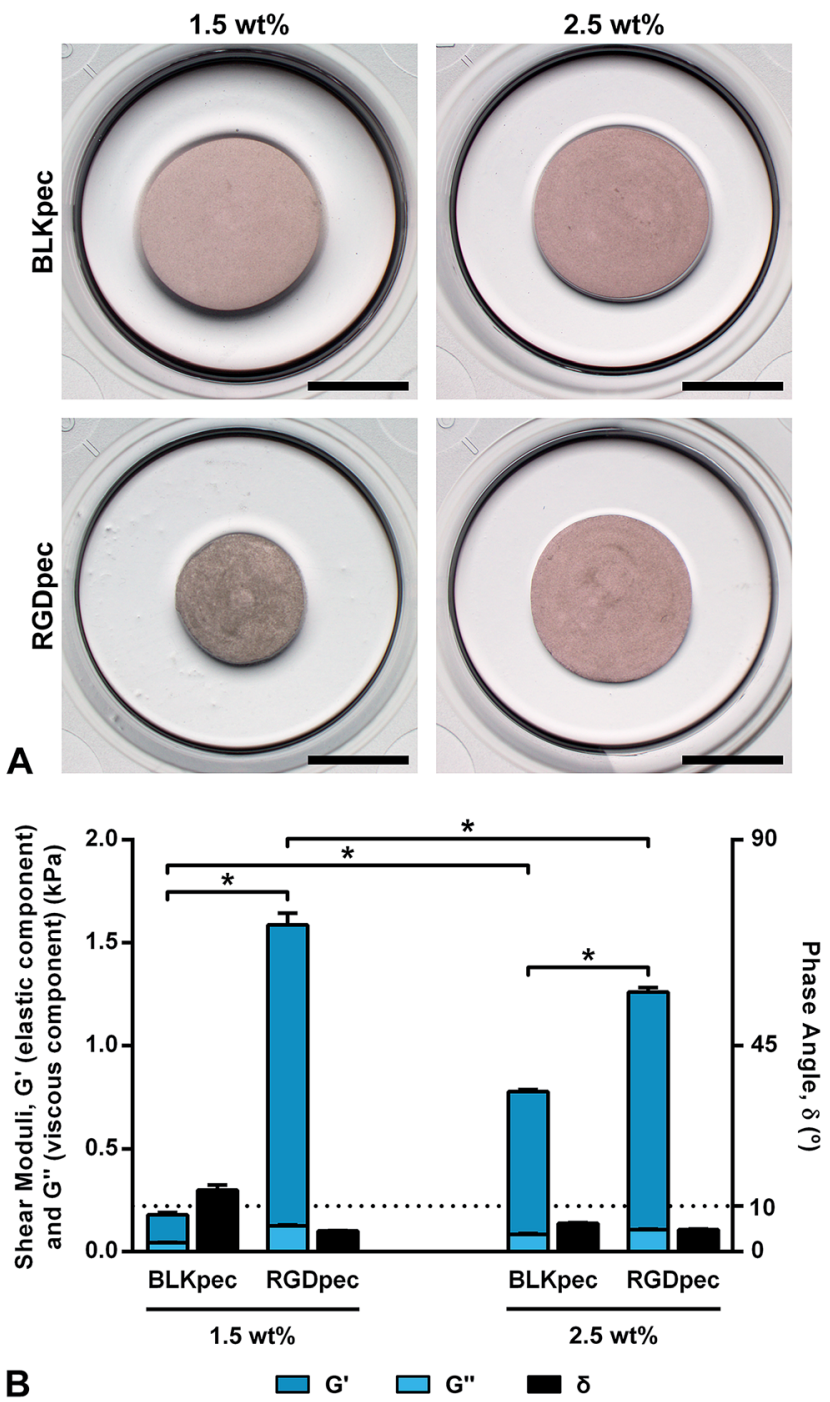

Fig. 5 (a) Macroscopic appearance of the different pectin hydrogel discs loaded with human mesenchymal stem cells (hMSCs) after 7 days of culture (scale bars: $500 \mu \mathrm{m}$ ) and (b) corresponding viscoelastic properties (elastic $\left(G^{\prime}\right)$ and viscous $\left(G^{\prime \prime}\right)$ components of the shear moduli, and phase angle $(\delta))$. * denotes statistically significant differences $(p<0.05)$ between $G^{\prime}$ values.

hydrogels, this difference being more noticeable for the $1.5 \mathrm{wt} \%$ RGDpec hydrogels. The viscoelastic properties of these cell-laden hydrogels (Fig. 5B) were also different. Both $1.5 \mathrm{wt} \%$ and $2.5 \mathrm{wt} \%$ RGDpec hydrogels presented higher shear moduli than the BLKpec hydrogels. When comparing the RGDpec hydrogels, the $1.5 \mathrm{wt} \%$ hydrogels were the ones with higher shear moduli, especially concerning the elastic component $\left(G^{\prime}\right)$.

The representative image in Fig. 6A shows both the inside and the outside of part of a $2.5 \mathrm{wt} \%$ RGDpec hydrogel after 14 days of culture, with spread hMSCs both within and outside the hydrogel, establishing an inter-cellular network. The surface of this hydrogel (Fig. 6B) shows the spread hMSCs along with a fibronectin mesh of the endogenous ECM produced.
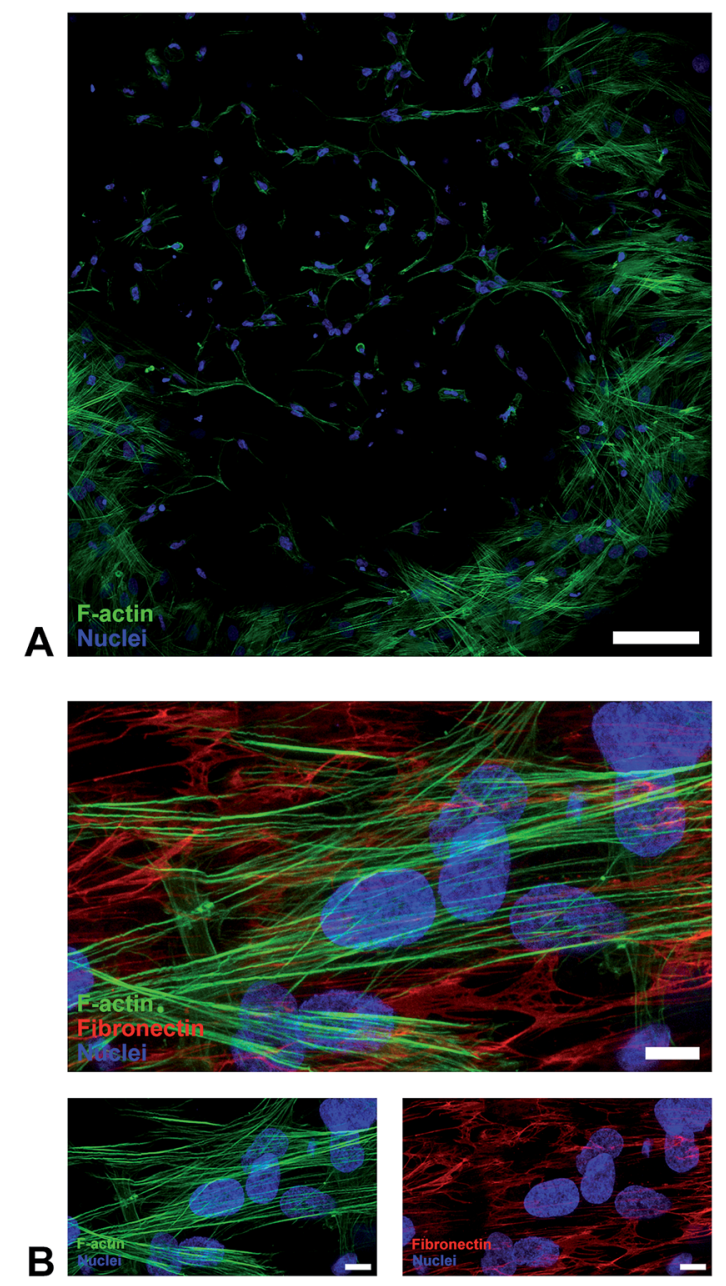

Fig. 6 (a) Representative image of the interior and exterior of part of a 2.5 wt\% RGDpec hydrogel with embedded human mesenchymal stem cells (hMSCs) after 14 days of culture, stained for F-actin (green) and nuclei (blue) (scale bars: $100 \mu \mathrm{m}$ ) and (b) cells on the surface of the hydrogel, stained for F-actin (green), fibronectin (red) and nuclei (blue) (scale bars: $10 \mu \mathrm{m}$ ).

\section{Subcutaneous implantation of pectin hydrogels}

After the in vitro characterization of RGDpec hydrogels, a preliminary study was performed to understand how these hydrogels degrade in vivo. The implantation of the hydrogels was performed by creating subcutaneous pockets on the dorsum of mice. After one week, mice were euthanized and the autopsy of the implantation site revealed modifications in the morphology of the hydrogel discs, for both $1.5 \mathrm{wt} \%$ and $2.5 \mathrm{wt} \%$ compositions (Fig. 7A). With the naked eye, the $2.5 \mathrm{wt} \%$ RGDpec hydrogels were easier to identify than the $1.5 \mathrm{wt} \%$ hydrogels. These results were further confirmed by the histological analysis of the implantation site (Fig. 7B). The Safranin-O/Lightgreen staining was used to localize the RGDpec hydrogel fragments, since Safranin-O is a basic stain that strongly binds to negatively charged polysaccharides, ${ }^{7}$ providing a high contrast orange staining against the surrounding tissue (green), and therefore easier identification. As observed from Fig. 7B, the $2.5 \mathrm{wt} \%$ RGDpec hydrogel appeared to be localized in a single 

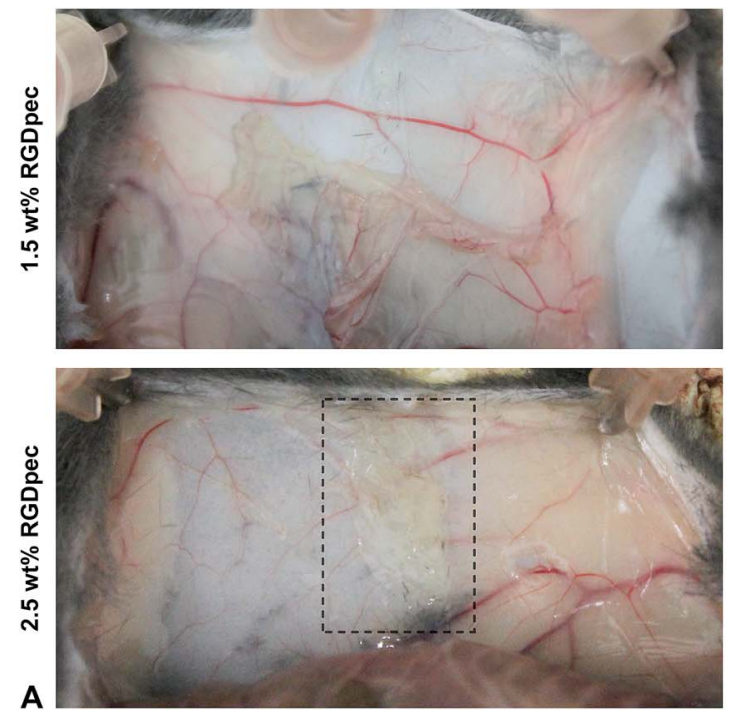

Fig. 7 In vivo degradation of RGDpec hydrogels as a function of pectin concentration (1.5 wt\% or 2.5 wt $\%$ ) after one week of subcutaneous implantation. (a) Representative photographs of the retrieved tissue samples. The area delimited by the dashed-line identifies the region where the $2.5 \mathrm{wt} \%$ RGDpec hydrogel can be observed with the naked eye. (b) Representative images of Safranin-O/Light-green-stained tissue sections. The pictures on the right-side (scale bar: $100 \mu \mathrm{m}$ ) are magnifications of the areas delimited by a straight black line on the pictures at a lower magnification (scale bar: $1 \mathrm{~mm}$ ) (orange: pectin, also identified with *; green: host tissue; purple/black: nuclei).

area, presenting fragmentation and tissue invasion. For the 1.5 $\mathrm{wt} \%$ hydrogel, the fragments were not localized in a single island, but spread throughout the mouse tissue, with single fragments afar from each other. Despite these differences, both formulations presented degradation and tissue invasion, with cells surrounding the hydrogel, establishing a network both around and inside it.

\section{Discussion}

Biopolymers are usually "low-cost" sources of biomaterials, and present a number of other advantages for biomedical applications, as previously described. However, when extracted, they often possess contaminants that must be removed for further use inside the human body. Thus, and prior to any study, the raw Classic CU 701 pectin (Herbstreith \& Fox) was purified adapting the protocol described by Bender et al. ${ }^{31}$ Many methodologies have been described for the purification of biopolymers ${ }^{31,39-41}$ for biomedical applications, which focused on the removal of foreign proteins, polyphenols and endotoxins. Nevertheless, most of those methodologies are not suitable for pectin purification mainly due to the $\mathrm{pH}$ and temperature shifts involved, which would lead to pectin depolymerization. This can occur by acid hydrolysis or $\beta$ elimination, depending on the $\mathrm{DM}$ and $\mathrm{pH}$ of pectin. In this work, the purification was performed at room temperature at pH 6 and, under these conditions, pectins are stable in solution. ${ }^{\mathbf{4 2 4 3}}$ This is in accordance with the SEC analysis performed, from which it could be concluded that the $M_{\mathrm{w}}$ of PURpec is not different from the $M_{\mathrm{w}}$ of RAWpec. The value determined for the $M_{\mathrm{w}}$ of RAWpec by SEC is in agreement with the values previously reported in the literature ${ }^{\mathbf{4 4 4 5}}$ for the same Herbstreith \& Fox Classic CU701 pectin (with similar
GalA unit content and DM), despite being from different batches.

The use of detergents for the removal of endotoxins and chloroform/n-butanol extraction methodology for the removal of foreign proteins has also been reported for biopolymer purification..$^{31,46,47}$ However, one of the objectives of this work was to establish a simple and cost-effective purification method for pectin, avoiding high amplitude $\mathrm{pH} /$ temperature shifts and the use of organic solvents or detergents. Activated charcoal has been reported to successfully adsorb different types of compounds, like phenolic compounds ${ }^{48}$ and endotoxins. ${ }^{49}$ In summary, by using activated charcoal, filter membranes, and ultracentrifugation at room temperature, the level of all major contaminants decreased more than $50 \%$, with the highlight being a decrease of $96 \%$ in the endotoxin content, without altering the physico-chemical properties of pectin. From the FTIR spectroscopic analysis, the pectin characteristic bands were present in both RAWpec and PURpec spectra. However, the intensity of the signal of $\mathrm{COO}^{-}$bands in PURpec, BLKpec and RGDpec spectra increased, which can be explained by the partial deprotonation of carboxylic groups associated with $\mathrm{pH}$ increase during the purification procedure (pectin $\left.\mathrm{p} K_{\mathrm{a}}=3.5\right){ }^{28}$ This is in accordance with studies concerning pectin extraction from raw biomass under alkaline conditions. For example, Cárdenas et $a l .{ }^{50}$ reported the appearance of bands associated with symmetric and asymmetric $\mathrm{COO}^{-}$stretching vibrations, centered approximately at 1600-1650 and 1400-1450 $\mathrm{cm}^{-1}$, respectively. After purification, pectin was successfully biofunctionalized with an RGD-containing peptide, since it does not intrinsically possess cell adhesive cues. ${ }^{\mathbf{1 1}}$ It was not possible to identify the amide groups of RGD in the RGDpec FTIR spectrum as these were overlapped by the pectin bands: the stretching of the carbonyl of the amide group was overlapped by 
the stretching of all other carbonyls in the same regions, and the $-\mathrm{NH}$ stretching was masked by the strong absorption of the $-\mathrm{OH}$ groups.

To our knowledge, the internal ionic gelation of pectin as an in situ gelling cell carrier system for tissue engineering applications has never been explored using the $\mathrm{CaCO}_{3} / \mathrm{GDL}$ system. Since the pre-requisites of pectin gelation conditions and kinetics used in the food or pharmaceutical industry are different from those used in medical applications, this had to be optimized. The goal was to develop pectin hydrogels that would (i) gelify under physiological conditions, (ii) within a clinically acceptable time-frame, adequate for an in situ gelling system. This means that the pectin hydrogels should start gelling only after the injection of the mixture of all the components (polymer, gelation agents, cells), although the stabilization of the viscoelastic properties of the injected cellloaded hydrogels can take longer. The first step was to determine the optimal concentrations of $\mathrm{CaCO}_{3}$ and GDL. Studies of gelation kinetics were performed with a fixed stoichiometric ratio between carboxyl groups and calcium ion concentration (eqn (1), $R=1$ ), varying the GDL concentration (eqn (2), $\left.R_{\text {Ca-GDL }}=0.5 / 0.25 / 0.125\right)$. According to the gelation kinetics, it is relatively easy to modulate the speed at which the pectin solutions gelify, i.e., present a more "solid-like" state $\left(\delta<10^{\circ}\right)$. With any of the three ratios tested, pectin hydrogels presenting a more "solid-like" state could be obtained within only $30 \mathrm{~min}$ at $37{ }^{\circ} \mathrm{C}$, corroborating the versatility of this system. The combination chosen $\left(R=1, R_{\mathrm{Ca}-\mathrm{GDL}}=0.5\right)$ for further studies was the one that allowed the slowest transition from the "liquid-like" state to the more "solid-like" state, thus being more suitable for cell entrapment.

Pectin gelation studies were performed to first evaluate if the purification process influenced the gelation and consequently the viscoelastic properties. From the obtained results, the PURpec solutions attained a "solid-like" behavior more rapidly (1.5 wt $\%$ - $18 \mathrm{~min} ; 2.5 \mathrm{wt} \%$ - $6 \mathrm{~min}$ ) than the RAWpec solutions (1.5 wt\% - $30 \mathrm{~min} ; 2.5 \mathrm{wt} \%-12 \mathrm{~min})$. After $1 \mathrm{~h}$ or $2 \mathrm{~h}$, the PURpec solutions also presented higher shear moduli. This might be mainly due to the removal of impurities during the purification procedure, which allowed better accessibility to $\mathrm{COO}^{-}$for the $\mathrm{Ca}^{2+}$ in order to establish the "egg-box" zones. The presence of RGD did not influence the gelation kinetics of pectin. Finally, the presence of the hMSCs did not affect the crossover time, but had a slight impact on the viscoelastic properties of the hydrogels (e.g. when comparing the shear moduli $1 \mathrm{~h}$ after the gelation has been triggered). This might be due to the fact that cells physically interfere with the crosslinking, affecting the establishment of "egg box" junction zones between some polymer chains.

Concerning the cell behavior within hydrogels, a cell delivery system has to assure that cells remain viable and metabolically active within the carrying matrix, to allow further interactions with the host tissue. The present results showed that entrapped hMSCs were metabolically active and viable throughout the culture time within all pectin hydrogels, regardless of their structural differences (mesh size and viscoelasticity). However, major differences were found in terms of cell morphology and behavior, as both the modifications in the pectin matrix chemistry (the RGD-grafting) and their physical properties (1.5 wt\% and $2.5 \mathrm{wt} \%$ ) influenced the behavior of hMSCs. CellRGDpec matrix interaction is mediated by integrins, a large family of transmembrane, heterodimeric receptors that bind to specific amino acid sequences like the RGD recognition motif, which is present in all major ECM proteins. ${ }^{51}$ This interaction has been extensively studied in the field and hMSCs respond differently in the presence of this peptide. ${ }^{52}$ Regardless of pectin concentration, remarkable differences could be observed in terms of cell morphology, when comparing hMSCs embedded within the pectin matrices functionalized and non-functionalized with RGD. Within the RGDpec matrices, hMSCs were able to spread and establish contacts with each other, leading to the recreation of an intercellular network or a microtissue. Moreover, they were able to migrate outwards the matrix, populating the surface of the hydrogels and depositing endogenous ECM. The opposite could be observed for the non-functionalized matrices, within which the hMSCs remained round-shaped throughout the 14 days culture period. This modification of pectin with RGD was only reported by our group, ${ }^{18,19}$ on which the spreading of MC3T3 cells was also observed within RGD functionalized pectin microspheres, obtained by an external gelation mechanism using $\mathrm{CaCl}_{2}$. Interestingly, cells were also capable of migrating out from the RGD-pectin microspheres and establish a cellular network connecting adjacent microspheres.

As both $1.5 \mathrm{wt} \%$ and $2.5 \mathrm{wt} \%$ RGD-modified matrices possess the same RGD density, differences in the morphology of hMSCs within these matrices are probably associated with the structural properties of hydrogels, namely their mesh size and viscoelasticity. The hMSCs were able to more easily spread and establish cellular networks within the $1.5 \mathrm{wt} \%$ RGDpec hydrogels as these are more compliant and provide more free space (larger mesh) than the $2.5 \mathrm{wt} \%$ matrices, facilitating that process.

After 7 days of culture, the stiffness of RGDpec matrices (shear moduli) was higher when compared to the stiffness of BLKpec matrices. However, the stiffness of the $1.5 \mathrm{wt} \%$ RGDpec hydrogels was even higher than that of the $2.5 \mathrm{wt} \%$ RGDpec matrices. This could be due to a combination of different factors. As the $1.5 \mathrm{wt} \%$ RGDpec matrices are softer and the polymeric network is less dense, they offer less resistance for cells to exert "tracking" forces to deform the surrounding matrix, when compared to the $2.5 \mathrm{wt} \%$ RGDpec hydrogels, leading to the matrix contraction observed with the naked-eye. In this way, cells were able to establish a denser cellular network. A similar behavior was observed for fibroblasts embedded within metalloproteinase (MMP)sensitive poly(ethylene glycol) (PEG) gels with different dry mass concentrations. ${ }^{53}$ At the same time, the eventual deposition of endogenous ECM by the hMSCs might have also contributed to these higher shear moduli values. This correlation between softer matrices, denser cellular networks and concomitant higher endogenous ECM content was previously reported for hMSCs embedded within alginate matrices. ${ }^{54,55}$ 
Depending on the application of a biomaterial, its degradation rate has to be well tuned. In the case of pectin, previous in vitro tests indicated its potential degradability under simulated physiological conditions, ${ }^{19}$ especially in comparison with other polysaccharides most widely studied for cell entrapment and encapsulation, such as alginate and chitosan. However, no clear indication of pectin in vivo degradation is available in the literature, where only a few preliminary studies can be found..$^{20,21}$ In the present work, it was intended to further clarify the degradation behavior of pectin through subcutaneous implantation of RGDpec hydrogels of $1.5 \mathrm{wt} \%$ and $2.5 \mathrm{wt} \%$ in the dorsum of mice. These two concentrations of pectin, selected due to the previously explained results, confer different viscoelastic properties to the hydrogels. Whether the polymer concentration can also affect the degradation rates of hydrogels without the presence of the laden cells was also an important aspect to be explored. As expected, and as previously reported for similar hydrogels, ${ }^{7}$ a lower polymer content in the hydrogels leads to a higher degradation rate. After 7 days of implantation, the $1.5 \mathrm{wt} \%$ hydrogels presented a higher number of fragments, which were smaller and more spread throughout than the ones of the $2.5 \mathrm{wt} \%$ hydrogels. For the latter, less and larger fragments could be observed, isolated and surrounded by the host tissue. By only changing the concentration of the RGDpec hydrogels, the degradation rate can be adjusted for a specific tissue and/or for the entrapment of specific cells in the hydrogels, in terms of their demands regarding viscoelastic properties.

As previously mentioned, only a few studies are available addressing the implantation of pectin hydrogels in animal models. $^{20,21}$ Takei and co-workers subcutaneously injected nonpurified, enzymatically crosslinked sugar beet pectin (SBP) gels and reported that the implanted gels maintained the initial volume at least for three weeks at the injection sites. ${ }^{20}$ In a second study, the same authors mixed SBP with gelatin in order to increase the degradability of the gels ${ }^{21}$ and reported that, one week post-injection, the SBP/gelatin gels presented an advanced state of degradation when compared to the SBP gels alone. Despite the interesting insights provided by these studies, it is difficult to establish comparisons with the present work since the origin of pectin, its processing (not purified), and the crosslinking methods are different. We also believe that no direct comparisons should be made between different hydrogels, due to known differences in chemistry, molecular weight, mass content, crosslinking mechanism, etc. However, if we (roughly) compare our results with in vivo studies of ionically crosslinked alginate hydrogels, which is the polysaccharide used in tissue engineering and regenerative medicine applications most similar to pectin, the extent of degradation of the 2.5 wt\% RGDpec hydrogels after only one week of subcutaneous implantation is similar to the degradation of $2 \mathrm{wt} \%$ oxidized alginate hydrogels after $\operatorname{six}^{56}$ or four ${ }^{7}$ weeks of subcutaneous implantation. Although we consider that the fast degradation rate is a relative property, as it is dependent on the aim of the study, it could be interesting for an application in which fast cell proliferation and production of the extracellular matrix are desirable.
This study represents an initial assessment of the in vivo performance of RGDpec hydrogels. Further studies are required to better elucidate the in vivo behavior of pectin. However, the results of the present work clearly show how versatile pectin hydrogels can be, and also how fast they can degrade without the need for extensive chemical modifications.

\section{Conclusions}

The use of in situ-forming pectin hydrogels as cell carriers for tissue engineering and regenerative medicine strategies was addressed for the first time in this work. Pectin was purified using a simple and cost-effective method using activated charcoal that did not affect its physico-chemical properties. Pectin was further successfully grafted with an RGD-containing peptide to promote cell-matrix adhesion. The ionotropic gelation of pectin using the slow-gelling $\mathrm{CaCO}_{3} / \mathrm{GDL}$ system was optimized within an adequate time-frame for in situ gelling systems. hMSCs embedded within the pectin hydrogels were viable and metabolically active for at least 14 days of culture. Moreover, they established intercellular networks within the RGD-modified pectin hydrogels, migrated outwards the matrix, and produced endogenous ECM. From the preliminary in vivo study performed, pectin hydrogels presented an advanced degradation state after only one week of sub-cutaneous implantation. Along with other pharmaceutical and medical applications of pectin, the results from this study show the promising capabilities of pectin hydrogels to be used as biomaterials for cell delivery in tissue engineering and regenerative medicine applications.

\section{Acknowledgements}

The authors would like to acknowledge Herbstreith \& Fox (Neuenbürg, Germany) for kindly providing the pectin used in this study. This work was financed by the European Regional Development Fund (ERDF) through the Programa Operacional Factores de Competitividade - COMPETE, and by Portuguese funds through FCT - Fundação para a Ciência e a Tecnologia in the framework of a doctoral grant SFRH/BD/76995/2011 to S. C. Neves, a post-doctoral grant SFRH/BPD/90047/2012 to A. Sousa, a post-doctoral grant SFRH/BPD/80571/2011 to S. J. Bidarra, the research position of C. C. Barrias (Ciência 2008) funded by FCTPOPH-FSE, the research grant PEst-C/SAU/LA0002/2011, and cofinanced by North Portugal Regional Operational Programme (ON.2 - O Novo Norte) in the framework of the project SAESCTN-PIIC\&DT/1/2011, under the National Strategic Reference Framework (NSRF).

\section{References}

1 J. L. Drury and D. J. Mooney, Biomaterials, 2003, 24, 43374351.

2 B. Alberts, D. Bray, J. Lewis, M. Raff, K. Roberts and J. Watson, Molecular Biology of the Cell, Garland Publishing, Inc., New York, 1994. 
3 K. Y. Lee and D. J. Mooney, Prog. Polym. Sci., 2012, 37, 106126.

4 T. Hao, N. Wen, J.-K. Cao, H.-B. Wang, S.-H. Lü, T. Liu, Q.-X. Lin, C.-M. Duan and C.-Y. Wang, Osteoarthritis Cartilage, 2010, 18, 257-265.

5 D. P. Vasconcelos, A. C. Fonseca, M. Costa, I. F. Amaral, M. A. Barbosa, A. P. Águas and J. N. Barbosa, Biomaterials, 2013, 34, 9952-9959.

6 K. B. Fonseca, S. J. Bidarra, M. J. Oliveira, P. L. Granja and C. C. Barrias, Acta Biomater., 2011, 7, 1674-1682.

7 K. B. Fonseca, D. B. Gomes, K. Lee, S. G. Santos, A. Sousa, E. A. Silva, D. J. Mooney, P. L. Granja and C. C. Barrias, Biomacromolecules, 2014, 15, 380-390.

8 E. G. Maxwell, N. J. Belshaw, K. W. Waldron and V. J. Morris, Trends Food Sci. Technol., 2012, 24, 64-73.

9 I. Fraeye, T. Duvetter, E. Doungla, A. Van Loey and M. Hendrickx, Trends Food Sci. Technol., 2010, 21, 219-228.

10 F. Munarin, M. C. Tanzi and P. Petrini, Int. J. Biol. Macromol., 2012, 51, 681-689.

11 B. L. Ridley, M. A. O'Neill and D. Mohnen, Phytochemistry, 2001, 57, 929-967.

12 D. Durand, C. Bertrand, J. P. Busnel, J. R. Emery, M. A. V. Axelos, J. F. Thibault, J. Lefebvre, J. L. Doublier, A. H. Clark and A. Lips, in Physical Networks - Polymers and Gels, ed. W. Burchard and S. B. Ross-Murphy, Elsevier Applied Science Publishers, London, 1990, pp. 283-300.

13 J. Gigli, C. Garnier and L. Piazza, Food Hydrocolloids, 2009, 23, 1406-1412.

14 I. Eliaz, E. Weil and B. Wilk, Forsch. Komplementmed., 2007, 14, 358-364.

15 G. Perera, J. Barthelmes and A. Bernkop-Schnürch, J. Controlled Release, 2010, 145, 240-246.

16 J. Jiang, I. Eliaz and D. Silva, Integr. Cancer Ther., 2013, 12, 145-152.

17 Y. Li, L. Liu, Y. Niu, J. Feng, Y. Sun, X. Kong, Y. Chen, X. Chen, H. Gan, S. Cao and Q. Mei, Eur. J. Nutr., 2012, 51, 107-117.

18 F. Munarin, S. G. Guerreiro, M. A. Grellier, M. C. Tanzi, M. A. Barbosa, P. Petrini and P. L. Granja, Biomacromolecules, 2011, 12, 568-577.

19 F. Munarin, P. Petrini, M. C. Tanzi, M. A. Barbosa and P. L. Granja, Soft Matter, 2012, 8, 4731-4739.

20 T. Takei, K. Sugihara, H. Ijima and K. Kawakami, J. Biosci. Bioeng., 2011, 112, 491-494.

21 T. Takei, K. Sugihara, M. Yoshida and K. Kawakami, J. Biomater. Sci., Polym. Ed., 2013, 24, 1333-1342.

22 S. H. Jahromi, L. M. Grover, J. Z. Paxton and A. M. Smith, J. Mech. Behav. Biomed. Mater., 2011, 4, 1157-1166.

23 C. K. Kuo and P. X. Ma, Biomaterials, 2001, 22, 511-521.

24 S. J. Bidarra, C. C. Barrias, K. B. Fonseca, M. A. Barbosa, R. A. Soares and P. L. Granja, Biomaterials, 2011, 32, 78977904.

25 A. Ström, P. Ribelles, L. Lundin, I. Norton, E. R. Morris and M. A. Williams, Biomacromolecules, 2007, 8, 2668-2674.

26 R. R. Vincent and M. A. Williams, Carbohydr. Res., 2009, 344, 1863-1871.
27 M. Audebrand, M. Kolb and M. A. Axelos, Biomacromolecules, 2006, 7, 2811-2817.

28 H. R. Moreira, F. Munarin, R. Gentilini, L. Visai, P. L. Granja, M. C. Tanzi and P. Petrini, Carbohydr. Polym., 2014, 103, 339-347.

29 S. J. Bidarra, C. C. Barrias and P. L. Granja, Acta Biomater., 2014, 10, 1646-1662.

30 A. M. DiMarino, A. I. Caplan and T. L. Bonfield, Front. Immunol., 2013, 4, 201.

31 J. C. M. E. Bender and P. S. Vermeulen, WO Pat. 2009154440 A1, 2009.

32 G. Skjåk-Bræk, E. Murano and S. Paoletti, Biotechnol. Bioeng., 1989, 33, 90-94.

33 J. A. Rowley, G. Madlambayan and D. J. Mooney, Biomaterials, 1999, 20, 45-53.

34 M. B. Evangelista, S. X. Hsiong, R. Fernandes, P. Sampaio, H.-J. Kong, C. C. Barrias, R. Salema, M. A. Barbosa, D. J. Mooney and P. L. Granja, Biomaterials, 2007, 28, 3644-3655.

35 N. Huebsch, P. R. Arany, A. S. Mao, D. Shvartsman, O. A. Ali, S. A. Bencherif, J. Rivera-Feliciano and D. J. Mooney, Nat. Mater., 2010, 9, 518-526.

36 J. Folkman and A. Moscona, Nature, 1978, 273, 345-349.

37 G. A. Morris, J. G. de la Torre, A. Ortega, J. Castile, A. Smith and S. E. Harding, Food Hydrocolloids, 2008, 22, 1435-1442.

38 S. M. Oliveira, C. C. Barrias, I. F. Almeida, P. C. Costa, M. R. P. Ferreira, M. F. Bahia and M. A. Barbosa, J. Biomed. Mater. Res., Part B, 2008, 87, 49-58.

39 A. Prokop and T. G. Wang, Ann. N. Y. Acad. Sci., 1997, 831, 223-231.

40 P. de Vos, B. J. de Haan, G. H. J. Wolters, J. H. Strubbe and R. von Schilfgaarde, Diabetologia, 1997, 40, 262-270.

41 G. Klöck, A. Pfeffermann, C. Ryser, P. Gröhn, B. Kuttler, H.-J. Hahn and U. Zimmermann, Biomaterials, 1997, 18, 707-713.

42 J. N. BeMiller, in Chemistry and Function of Pectins, ed. M. L. Fishman and J. J. Jen, American Chemical Society (ACS) Symposium Series, 3rd edn, 1986, pp. 2-12.

43 S. M. Brejnholt, in Food Stabilisers, Thickeners and Gelling Agents, ed. A. Imeson, Wiley-Blackwell, 2009, pp. 237-265.

44 F. Munarin, S. Bozzini, L. Visai, M. C. Tanzi and P. Petrini, Food Hydrocolloids, 2013, 31, 74-84.

45 S. V. Popov, P. A. Markov, G. Y. Popova, I. R. Nikitina, L. Efimova and Y. S. Ovodov, Biomed. Prev. Nutr., 2013, 3, 59-63.

46 L. N. Beenken-Rothkopf, L. S. Karfeld-Sulzer, X. Zhang, H. Kissler, S. A. Michie, D. B. Kaufman, M. J. Fontaine and A. E. Barron, J. Biomater. Appl., 2013, 28, 395-406.

47 X. Wang, Y. Yuan, K. Wang, D. Zhang, Z. Yang and P. Xu, J. Biotechnol., 2007, 128, 403-407.

48 A. Dąbrowski, P. Podkościelny, Z. Hubicki and M. Barczak, Chemosphere, 2005, 58, 1049-1070.

49 S. R. Sandeman, C. A. Howell, G. J. Phillips, A. W. Lloyd, J. G. Davies, S. V. Mikhalovsky, S. R. Tennison, A. P. Rawlinson, O. P. Kozynchenko, H. L. H. Owen, J. D. S. Gaylor, J. J. Rouse and J. M. Courtney, Biomaterials, 2005, 26, 7124-7131. 
50 A. Cárdenas, F. M. Goycoolea and M. Rinaudo, Carbohydr. Polym., 2008, 73, 212-222.

51 M. D. Pierschbacher and E. Ruoslahti, Nature, 1984, 309, 3033.

52 J. Lam and T. Segura, Biomaterials, 2013, 34, 3938-3947.

53 K. Bott, Z. Upton, K. Schrobback, M. Ehrbar, J. A. Hubbell, M. P. Lutolf and S. C. Rizzi, Biomaterials, 2010, 31, 84548464.
54 F. R. Maia, A. H. Lourenço, P. L. Granja, R. M. Gonçalves and C. C. Barrias, Macromol. Biosci., 2014, 14, 759-771.

55 F. R. Maia, K. B. Fonseca, G. Rodrigues, P. L. Granja and C. C. Barrias, Acta Biomater., 2014, 10, 3197-3208.

56 E. Alsberg, H. J. Kong, Y. Hirano, M. K. Smith, A. Albeiruti and D. J. Mooney, J. Dent. Res., 2003, 82, 903-908. 